\title{
Texture evaluation of whey protein concentrate incorporated ice cream by Back Extrusion technique
}

\author{
Hoda Mahmoud Mohamed El-Zeini* ${ }^{* 1}$, Abdel-Rahman Abdel-Atti Ali ${ }^{1}$, Rezk Azab \\ Awad $^{2}$, Yasser Farouk Hassan Abd El-Ghany3
}

${ }^{1}$ Dairy Science and Technology Department, Faculty of Agriculture, Cairo University, Egypt.

${ }^{2}$ Dairy Science, Faculty of Agriculture, Ain Shams University.

${ }^{3}$ Food Technology Research Institute, Agriculture Research Center, Giza, Egypt.

\begin{abstract}
Back extrusion technique was employed to evaluated texture properties of partial substituted whey protein concentrate (WPC) with milk solids not fat (1, 2, 3 and $4 \%$ ) in ice cream formula.

There was no remarkable effect of adding WPC on total solids or fat \%. Total protein increased, while ash, and lactose content were significantly decreased.

Back-extrusion results represented a decrease in hardness values of resultant ice cream, while, during storage, there was a slight increase. Energy input values decreased by increasing substitution levels of WP. Although, energy output inversely correlated with substitution levels of WP it correlated with storage period indicating a strong structure for stored ice cream. Load at target deformation (50\%) applied to the samples when fresh and after 14 days storage showing decreased values proportional to increasing substitution levels of WP. The resilience showed decreased ratio indicating more visco-elastic properties in fresh ice cream. The recovered height and deformation increased with increasing substitution levels of WP and storage period. Therefore, more sticking properties were obtained in resultant ice cream. Adhesive force decreased significantly with increasing substitution levels of WP and storage period. Adhesiveness values were significantly higher in all treatments than control.

The texture of the ice cream became smoother by replacing milk solid not fat with WPC up to 3\%. From the data obtained, it could be recommended that ice cream can be produced with high quality by substituting milk solid not fat with WPC up to $3 \%$.
\end{abstract}

Keywords - Ice cream, Texture properties, Texture profile analysis, Whey protein concentrate.

\section{INTRODUCTION}

Ice cream is one of the most consumed dairy products in the world [1]. It is an example of complex materials consisting of ice crystals, air bubbles and fat globules contained within a viscous liquid matrix [2].
Nowadays, separation technologies provide the basis for adding value to milk to meet specific needs such as improvement in texture [3]. The high nutritional value, the excellent functional properties and the source of biologically active peptides [4] that WPC contains have increased its use in food industry [5,6,7].

It is challenging to perform rheological measurements due to the complex structure of ice cream. The application of rheology is important when characterizing the behaviour of such complex soft solids [8].

Back extrusion test (sometimes called annular pumping) [9], has great potential in food industry, because it is a simple, rapid and low cost method. It's usually used for soft foods such as pastes and liquids, which can be tested in their own packaging to displace viscous liquids or semi-sold products not suitable for traditional viscometers in a controlled manner in order to assess characteristics such as flow, thinning and thickening, consistency, viscosity, adhesiveness and spreadability. Within dairy products such as yogurt and cream, this test will identify spoon-ability and flow properties of finished products. Back extrusion techniques are most commonly applied as they permit measurement of the sample in the container into which it was deposited or formed in. This removes any risk of disruption when decanting a sample and allows a more objective measure of semi-solids consistency.

However, several authors were used back extrusion test to evaluate the mechanical characterization for many products (i.e., Yoghurt, [10;11;12;13 and 14], Stirred yoghurt; [15;16;17;18;19 and 20], Misti Dahi, [21], Whipped creams; [22], Extruded whey protein concentrate (WPC) and extruded whey protein isolate (WPI); [23], Ricotta cheese; [24] Cottage Cheese; [25], Cooked and canned legumes; [26], Sauces; [27], Custard; [28], Mashed potatoes; [29], Molten chocolate; [30], Food hydrocolloids; [31], Starches such as corn, wheat, and cassava; [32]. 
This study focuses on providing novel bioactive ingredients as WPC, with the objective of replacing the conventional ingredients, to ice cream. Moreover, setting the best ratio of WPC incorporated in ice cream formulas depending on chemical and textural properties measured by back extrusion technique.

\section{MATERIALS AND METHODS}

\subsection{Materials}

Fresh buffalo's skim (90.9 \% moisture, $0.1 \%$ fat, $3.4 \%$ protein, $4.9 \%$ lactose and $0.7 \%$ ash) and fresh concentrated cream $(29.4 \%$ moisture, $67 \%$ fat, $1.3 \%$ protein, $1.7 \%$ lactose and $0.6 \%$ ash) were obtained from the herd of Faculty of Agriculture, Cairo University and used for preparing the ice cream mixes. Low heat skim milk powder (SMP) (3.8\% moisture, $0.8 \%$ fat, $33.4 \%$ protein, $54.1 \%$ lactose and $7.9 \%$ ash) was obtained from Abou El-Hool-Import/Export Co., Cairo, Egypt. Whey protein concentrate powder $(4.7 \%$ moisture, $5.9 \%$ fat, $77.7 \%$ protein, $9.1 \%$ lactose and $2.6 \%$ ash) was supplied by Davisco Foods International, Inc, USA. Commercial grade sugar cane was obtained from the local market, Sodium carboxymethyl cellulose (CMC) as a stabilizer was obtained from Mifad Company, Giza, Egypt. Vanilla was obtained from the local market and used to flavour final ice cream.

\subsubsection{Manufacture of Ice cream:}

Ice cream mix contained $8 \%$ fat, $12 \%$ milk solid not fat, $15 \%$ sucrose, $0.25 \%$ stabilizer. Skimmed milk powder was substituted with WPC at 1.0, 2.0, 3.0 and 4.0\% of dried milk solids not fat in the base mix (Table 1).

\begin{tabular}{|c|c|c|c|c|c|}
\hline \multirow{2}{*}{ Ingredients } & \multirow{2}{*}{ Control } & \multicolumn{4}{|c|}{ Level of substitution $(\mathrm{g} / \mathrm{kg}$ mix $)$} \\
\hline & & $\mathrm{T} 1$ & $\mathrm{~T} 2$ & $\mathrm{~T} 3$ & $\mathrm{~T} 4$ \\
\hline Sugar & 150 & 150 & 150 & 150 & 150 \\
\hline Stabilizer & 2.5 & 2.5 & 2.5 & 2.5 & 2.5 \\
\hline Fresh skim milk & 670.38 & 670.38 & 670.38 & 670.38 & 670.38 \\
\hline Cream & 117.69 & 117.69 & 117.69 & 117.69 & 117.69 \\
\hline Dried skim milk & 59.43 & 48.94 & 38.16 & 27.08 & 17.10 \\
\hline WPC 80 & 0.00 & 11.18 & 22.17 & 33.05 & 43.04 \\
\hline Total & 1000 & 1000.69 & 1000.9 & 1000.7 & 1000.71 \\
\hline
\end{tabular}

T1, T2, T3, T4: Corresponding to 1, 2, 3 and 4\% WPC substitution of MSNF.

\subsection{Methods}

Total solids, total protein content and ash were determined according to [33]. Lactose content was determined according to [34]. Fat content was determined according to [35].

\subsubsection{Back Extrusion}

The back-extrusion test was carried out using the (TMSPro testing machine) equipped with (250 lbf) load cell and connected to a computer programmed with Pro $^{\mathrm{TM}}$ texture analysis software. Forty grams of ice cream sample were scooped in a cylindrical glass cup (height $70.1 \mathrm{~mm}$; diameter $43.6 \mathrm{~mm}$ ) and solidified for $24 \mathrm{hrs}$. at $-18^{\circ} \mathrm{C}$.

Sample surface was flattened to avoid early triggering of the test. A flat probe rod $(37.75 \mathrm{~mm}$ diameter $)$ was programmed to descend into the sample at a speed of 20 $\mathrm{mm} / \mathrm{sec}$ to a depth of $50 \%$ of original sample high (40 $\mathrm{mm}$ ) and then ascend back to its original position with a back-off distance of $20 \mathrm{~mm}$. Distance of extrusion was set at $20 \mathrm{~mm}$ with a trigger force of $1 \mathrm{~N}$. The force encountered by the probe to break contact with ice cream at the start of the ascending (point of maximum force) was measured.

\section{STATISTICAL ANAKYSIS}

Data were analysed statistically using the MSTAT-C (ver 2.10, MSU, USA.) package on a personal computer. All experiments were carried out in triplicates. Differences were considered significant at $\mathrm{P}<0.05$.

\section{RESULTS AND DISCUSSION}

4.1. Chemical properties of ice cream mixes:

Fat was adjusted in all mixes to almost $8 \%$ for recipe formula during the procedures. A proportional replacement of MSNF with WPC resulted in a significant increase $(\mathrm{P}<0.001)$ in protein contents of ice cream mixes (Table 2). The increase mainly due to the higher protein content of WPC (77.7\%) compared to SMP (33.4\%). The total protein content increased in an ascending order with increasing the ratio of WPC substitution being the highest at 4\% WPC with a high correlation (0.999). These data agreed with the findings of [36] and [37]. The usage of WPC as a MSNF replacer leads to a significant reduction $(\mathrm{P}<0.001)$ in ash content (Table 2). This decrease could be due to the differences in ash contents of WPC (2.6\%) and SMP (7.9\%). Coefficient correlation (-0.985) showed a tight inverse relationship between WPC and ash\%. The 
obtained results are in a harmony with the findings of [36] and [6].

Table.2: Chemical composition (\%) of ice cream mixes with different ratios of WPC.

\begin{tabular}{cccccc}
\hline Treatments & Total solids & Fat & Total protein & Ash & Lactose content \\
\hline Control & 36.96 & 8.23 & $4.37^{\mathrm{e}}$ & $1.073^{\mathrm{a}}$ & $7.98^{\mathrm{a}}$ \\
$\mathbf{T}_{\mathbf{1}}$ & 36.37 & 8.23 & $4.94^{\mathrm{d}}$ & $0.943^{\mathrm{b}}$ & $7.24^{\mathrm{b}}$ \\
$\mathbf{T}_{\mathbf{2}}$ & 36.24 & 8.20 & $5.65^{\mathrm{c}}$ & $0.883^{\mathrm{c}}$ & $6.51^{\mathrm{c}}$ \\
$\mathbf{T}_{\mathbf{3}}$ & 36.16 & 8.23 & $6.29^{\mathrm{b}}$ & $0.821^{\mathrm{d}}$ & $5.81^{\mathrm{d}}$ \\
$\mathbf{T}_{\mathbf{4}}$ & 36.29 & 8.20 & $6.92^{\mathrm{a}}$ & $0.750^{\mathrm{e}}$ & $5.42^{\mathrm{e}}$ \\
\hline
\end{tabular}

$(a, b, \ldots)$ means with unlike superscript letters were significantly different $(\alpha=0.05)$

Lactose values decreased with increasing the substitution level of WPC $(\mathrm{P}<0.001)$ in the mixes. The decrease is due to a lower content of lactose in WPC $(9.1 \%)$ than in SMP $(54 \%)$. However, WPC with low lactose content can be safely used at higher levels without concerning of sandiness development defect in ice cream [38].

\subsection{Texture properties of ice cream mixes}

\subsubsection{Hardness}

Hardness, defined as the peak force obtained during penetration of the probe through samples during back extrusion test. It gives an indication of the energy required to masticate the ice cream to a state ready for swallowing. However, replacing MSNF by WPC at different ratios decreased $(\mathrm{P}<0.001)$ the hardness values of resultant ice cream Table (3) as a negative correlation (-0.891) was obtained. During storage at $-18 \pm 1^{\circ} \mathrm{C}$ for 14 days, there was a significant $(\mathrm{P}<0.001)$ increase of ice cream hardness values for control and all treatments (Table 3).

\subsubsection{Energy input and output}

Energy input is defined as the total amount of energy recorded during down cycle of texture analyzer as an area (the area under the penetration cycle down stroke), or energy input to deform sample during compression. Energy input is an indicative of sample consistency and for example how structure resists mechanical condition imposed. Obtained results revealed that the energy input values decreased $(\mathrm{P}<0.001)$ by increasing substitution levels with WPC (-0.739). However data showed that the energy input values were significantly $(\mathrm{P}<0.001)$ lower in all treatments with WPC "Fig.1 A" than control (LSD=300.2 at $0.05 \alpha$ level).

Table 3. Back extrusion measured parameters for the resultant ice cream when fresh and after 14 days of storage at $-18 \pm 1^{\circ} \mathrm{C}$.

\begin{tabular}{lllllll}
\hline \multicolumn{1}{c}{ Parameters } & Storage & Control & T1 & T2 & T3 & T4 \\
\hline \multirow{2}{*}{ Hardness (N) } & Fresh & $67.00^{\mathrm{b}}$ & $64.5^{\mathrm{d}}$ & $54.00^{\mathrm{e}}$ & $38.10^{\mathrm{h}}$ & $38.00^{\mathrm{i}}$ \\
& 2 weeks & $67.13^{\mathrm{a}}$ & $67.1^{\mathrm{c}}$ & $65.3^{\mathrm{d}}$ & $51.3^{\mathrm{f}}$ & $44.6^{\mathrm{g}}$ \\
\hline \multirow{2}{*}{ Position of hardness $(\mathrm{mm})$} & Fresh & $16.47^{\mathrm{c}}$ & $18.58^{\mathrm{b}}$ & $19.79^{\mathrm{a}}$ & $19.86^{\mathrm{a}}$ & $19.91^{\mathrm{a}}$ \\
& 2 weeks & $16.64^{\mathrm{c}}$ & $18.93^{\mathrm{c}}$ & $19.80^{\mathrm{c}}$ & $19.91^{\mathrm{ab}}$ & $20.15^{\mathrm{b}}$ \\
\hline \multirow{2}{*}{ Recovered height $(\mathrm{mm})$} & Fresh & $1.56^{\mathrm{g}}$ & $1.707^{\mathrm{fg}}$ & $1.843^{\mathrm{fg}}$ & $3.673^{\mathrm{d}}$ & $5.793^{\mathrm{c}}$ \\
& 2 weeks & $2.20^{\mathrm{ef}}$ & $2.547^{\mathrm{e}}$ & $4.173^{\mathrm{d}}$ & $7.757^{\mathrm{b}}$ & $8.52^{\mathrm{a}}$ \\
\hline \multirow{2}{*}{ Modulus slop (N/mm) } & Fresh & $4.26^{\mathrm{a}}$ & $3.79^{\mathrm{b}}$ & $2.69^{\mathrm{c}}$ & $1.93^{\mathrm{d}}$ & $1.89^{\mathrm{d}}$ \\
& 2 weeks & $4.40^{\mathrm{a}}$ & $4.38^{\mathrm{a}}$ & $4.06^{\mathrm{ab}}$ & $2.64^{\mathrm{c}}$ & $2.32^{\mathrm{cd}}$ \\
\hline \multirow{2}{*}{ Adhesiveness force (N) } & Fresh & $-14.63^{\mathrm{a}}$ & $-14.23^{\mathrm{a}}$ & $-11.56^{\mathrm{b}}$ & $-11.00^{\mathrm{bc}}$ & $-10.16^{\mathrm{bc}}$ \\
\hline \multirow{2}{*}{ Adhesiveness } & 2 weeks & $-13.90^{\mathrm{a}}$ & $-13.66^{\mathrm{a}}$ & $-11.13^{\mathrm{bc}}$ & $-10.11^{\mathrm{bc}}$ & $-9.53^{\mathrm{c}}$ \\
\hline \multirow{2}{*}{ Mm to break adhesiveness contact } & Fresh & $479.60^{\mathrm{h}}$ & $520.36^{\mathrm{g}}$ & $737.22^{\mathrm{c}}$ & $767.89^{\mathrm{b}}$ & $856.33^{\mathrm{a}}$ \\
& 2 weeks & $445.27^{\mathrm{i}}$ & $483.17^{\mathrm{h}}$ & $565.13^{\mathrm{f}}$ & $625.99^{\mathrm{e}}$ & $668.9^{\mathrm{d}}$ \\
\hline
\end{tabular}

During storage of ice cream samples, there was a significant increase of energy input values over those of fresh ice cream $(\mathrm{P}<0.001)$. Moreover, the interaction of WPC\% and storage period affected the input energy $(\mathrm{P}<0.001)$ significantly.

Energy output is defined as the total amount of energy recorded during up cycle of texture analyzer as an area, energy returned from sample during decompression. It expresses the strength of the internal bonds of the sample. The more the energy output, the stronger the internal structure of the material. The energy output negatively correlated with WPC\% (-0.838) and positively with storage period which indicated a stronger structure of stored than fresh ice cream. While, WPC\% significantly 
affected energy output $(\mathrm{P}<0.001)$, storage period or the two factors interaction didn't affect energy output "Fig.1 B" .

\subsubsection{The load at target}

The load at target deformation (50\%) applied to the samples showed decreased values $(\mathrm{P}<0.001)$ proportional to increasing WPC\% in ice cream samples for fresh and 14 days storage "Fig. $1 \mathrm{C}$ " that indicated a slight harder ice cream texture. Neither WPC\% nor storage period affected time at target deformation $(\mathrm{P}>0.05)$.

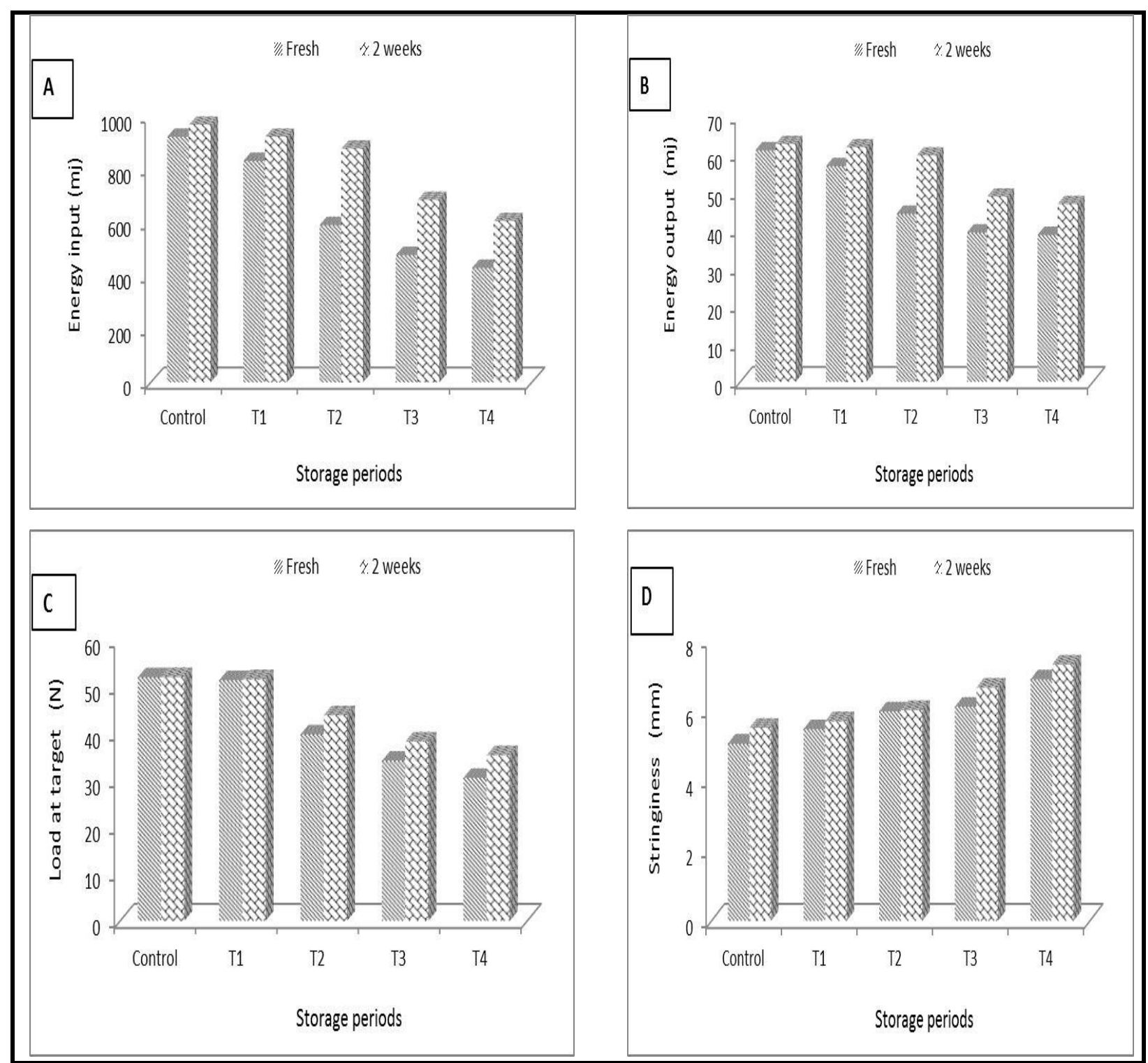

Fig.1: Back extrusion measured parameters; Energy input (A), Energy output (B), Load at target (C) and stringiness $(D)$ values of fresh and stored ice cream with different replacing ratio of WPC

\subsubsection{Resilience}

Resilience is a subjective measure of how the sample recovers. Ratio of energy input to energy returned. It provides an indication of unrecoverable work from the total deformation. The resilience showed decreased ratio $(\mathrm{P}<0.001)$ with a high $\mathrm{R}^{2}(0.941)$ indicating more viscoelastic properties in fresh ice cream. Stored ice cream showed high data variations with T2 which was more elastic than the rest of the treatments.

\subsubsection{Recovered height $(\mathrm{mm})$}

Distance sample remained in contact with test probe during upward cycle before recording negative values of adhesion. Highly viscous sample exhibits no recovery and adhesive properties. Highly elastic sample shows almost instant recovery. Therefore, ice cream samples exhibited visco-elastic property as a recovered height is obtained plus an adhesiveness value. As shown in Table (3) the elasticity of the samples decreased at the expense of viscosity as the recovered height increased $(\mathrm{P}<0.001)$ with increasing WPC\% and storage period. The 
displacement of 4\% WPC increased almost 3.7 times that of the control for fresh and 3.8 times for 14 days stored ice cream.

\subsubsection{Stringiness}

Stringiness length is defined as deformation at given negative force. Stringiness is used to determine maximum 'Stickiness' of sample. The distance a sample is extended during decompression before probe-sample interface is broken. The deformation increased with increasing WPC\% and storage period as indicated in (Fig. 1 D). Therefore, more sticking properties were obtained as a result of incorporating WPC or extending the storage period.

\subsubsection{Best Fit (mm.N)}

Rate at which distance increases per force during test $e . g$. higher distance values indicating softer samples. The best fitting line is drawn between loads at Mod-Point 1 and Mod-Point 2. Mod Point 1 is 5\% of target distance and Mod Point 2 is $10 \%$ of Target distance. Increasing the distance the plunger travels between Mod 1 and Mod 2 indicated weaker structures of the fresh ice cream treated with WPC or significant lower hardness $(\mathrm{P}<0.001)$. Number of $\mathrm{mm}$ traveled by the plunger in the ice cream fresh and stored samples per Newton increased which indicated softer texture.

\subsubsection{Modulus slop (N/mm)}

It is the rate at which force increases with deformation or sample resistance increases with increasing stress. Sensorial: rigidity or stiffness of sample in relation to imposed deformation or stress $\left(\mathrm{M} \quad \mathrm{L}^{-1} \quad \mathrm{~T}^{-2}=\right.$ Mass/Displacement $\mathrm{x}$ Time). The data indicated a decrease in rigidity of ice cream samples as a result of increasing WPC\% when fresh $(\mathrm{P}<0.001)$ or after 14 days of storage (Table 3). Additionally, the interaction of the two factors affected the modulus slop $(\mathrm{P}<0.05)$ significantly.

\subsubsection{Adhesive force}

Force required for breaking the contact with test probe. Sensorial, it is the stickiness of the sample when compressed between teeth or held in hand. Adhesive force decreased significantly (Tables 3) with increasing WPC\% and storage period $(\mathrm{P}<0.001)$. A decrease of the adhesiveness force with the increase of the WPC\% was obtained (-0.875).

\subsubsection{Adhesiveness}

Adhesiveness is recognized as Work $(\mathrm{J})$ required to break contact between the sample and probe. Total amount of energy input to break attractive forces between the sample and surface onto which it makes contact e.g. tongue, teeth, palette, fingers. Adhesiveness of resultant ice cream as affected by replacing MSNF by WPC at different ratios, fresh and after 14 days of storage at $-18 \pm 1^{\circ} \mathrm{C}$ was shown in Table (3). The adhesiveness values were significantly $(\mathrm{P}<0.001)$ higher in all treatments with WPC than control. During storage of ice cream, the adhesiveness values increased $(\mathrm{P}<0.001)$ gradually which indicated more stickiness of the ice cream with WPC and that stored for 14 days $\left(\mathrm{R}^{2}=0.951\right)$.

\subsubsection{Start of adhesiveness ( $\mathrm{mm})$}

A shifting in the adhesiveness start position for T4 was $7.67 \mathrm{~cm}$ compared to the control for WPC fresh ice cream. WPC\% caused that shifting in the start of adhesiveness position $(\mathrm{P}<0.001)$. Additionally, storage period and the interaction between the two factors increased the shifting $(\mathrm{P}<0.001)$ significantly. The shift for the stored ice cream was $9.82 \mathrm{~cm}$. The start of the adhesiveness $(\mathrm{mm})$ increased with increasing WPC\% as confirmed with the positive correlation (0.971).

Table 3. Back extrusion measured parameters for the resultant ice cream when fresh and after 14 days of storage at -

$18 \pm 1^{\circ} \mathrm{C}$

\begin{tabular}{|c|c|c|c|c|c|c|}
\hline Parameters & Storage & Control & T1 & $\mathbf{T 2}$ & T3 & T4 \\
\hline \multirow{2}{*}{ Hardness (N) } & Fresh & $67.00^{\mathrm{b}}$ & $64.5^{\mathrm{d}}$ & $54.00^{\mathrm{e}}$ & $38.10^{\mathrm{h}}$ & $38.00^{\mathrm{i}}$ \\
\hline & 2 weeks & $67.13^{\mathrm{a}}$ & $67.1^{\mathrm{c}}$ & $65.3^{\mathrm{d}}$ & $51.3^{\mathrm{f}}$ & $44.6^{\mathrm{g}}$ \\
\hline \multirow{2}{*}{$\begin{array}{l}\text { Position of hardness } \\
(\mathrm{mm})\end{array}$} & Fresh & $16.47^{\mathrm{c}}$ & $18.58^{\mathrm{b}}$ & $19.79^{\mathrm{a}}$ & $19.86^{\mathrm{a}}$ & $19.91^{\mathrm{a}}$ \\
\hline & 2 weeks & $16.64^{\mathrm{c}}$ & $18.93^{\mathrm{c}}$ & $19.80^{c}$ & $19.91^{\mathrm{ab}}$ & $20.15^{\mathrm{b}}$ \\
\hline \multirow{2}{*}{$\begin{array}{l}\text { Recovered height } \\
(\mathrm{mm})\end{array}$} & Fresh & $1.56^{\mathrm{g}}$ & $1.707^{\mathrm{fg}}$ & $1.843^{\mathrm{fg}}$ & $3.673^{\mathrm{d}}$ & $5.793^{c}$ \\
\hline & 2 weeks & $2.20^{\mathrm{ef}}$ & $2.547^{\mathrm{e}}$ & $4.173^{\mathrm{d}}$ & $7.757^{b}$ & $8.52^{\mathrm{a}}$ \\
\hline \multirow{2}{*}{$\begin{array}{l}\text { Modulus slop } \\
(\mathrm{N} / \mathrm{mm})\end{array}$} & Fresh & $4.26^{\mathrm{a}}$ & $3.79^{b}$ & $2.69^{c}$ & $1.93^{\mathrm{d}}$ & $1.89^{\mathrm{d}}$ \\
\hline & 2 weeks & $4.40^{\mathrm{a}}$ & $4.38^{\mathrm{a}}$ & $4.06^{\mathrm{ab}}$ & $2.64^{\mathrm{c}}$ & $2.32^{\mathrm{cd}}$ \\
\hline \multirow{2}{*}{$\begin{array}{l}\text { Adhesiveness force } \\
\text { (N) }\end{array}$} & Fresh & $-14.63^{a}$ & $-14.23^{a}$ & $-11.56^{b}$ & $-11.00^{b c}$ & $-10.16^{b c}$ \\
\hline & 2 weeks & $-13.90^{a}$ & $-13.66^{a}$ & $-11.13^{b c}$ & $-10.11^{b c}$ & $-9.53^{c}$ \\
\hline \multirow{2}{*}{ Adhesiveness } & Fresh & $479.60^{\mathrm{h}}$ & $520.36^{\mathrm{g}}$ & $737.22^{\mathrm{c}}$ & $767.89^{\mathrm{b}}$ & $856.33^{a}$ \\
\hline & 2 weeks & $445.27^{\mathrm{i}}$ & $483.17^{\mathrm{h}}$ & $565.13^{\mathrm{f}}$ & $625.99^{\mathrm{e}}$ & $668.9^{\mathrm{d}}$ \\
\hline \multirow{2}{*}{$\begin{array}{l}\text { Mm to break } \\
\text { adhesiveness contact }\end{array}$} & Fresh & $13.78^{\mathrm{ef}}$ & $17.51^{\mathrm{b}}$ & $18.34^{\mathrm{b}}$ & $20.89^{a}$ & $21.22^{\mathrm{a}}$ \\
\hline & 2 weeks & $11.56^{\mathrm{g}}$ & $13.26^{\mathrm{f}}$ & $14.62^{\mathrm{de}}$ & $15.05^{\mathrm{cd}}$ & $16.06^{\mathrm{c}}$ \\
\hline
\end{tabular}




\subsubsection{Displacement at adhesive force $(\mathrm{mm})$}

Position of adhesiveness force is the biggest negative value from start position of adhesiveness until end of the test. Adhesive force is used to detect the end adhesive contact point prevents confusion in detecting end contact. If we do not set our reference points after the start adhesiveness contact points we will run the risk of detecting very early zero $\mathrm{N}$ points due to high data collection rates and changes in sample as probe retracts. In other words position of adhesiveness force is the maximum resistance to break contact with the sample e.g. stickiness to pull jaws apart or break contact with a surface. More stickiness of the ice cream samples was expressed by the displacement or the position of the adhesiveness force significantly $(\mathrm{P}<0.001)$ brought about by increasing proportionally the WPC\% (correlation $=0.983$ ), storage period and the interaction between the two factors (Table 5).

\subsubsection{Mm to break Adhesive Contact}

It is the distance sample remained in adhesive (negative value) contact with test probe during upward cycle before total contact is broken. Also, the distance sample stretches before breaking contact with test probe or test bed. The stretching of the ice cream sample increased with increasing WPC\% $(\mathrm{P}<0.001)$ and decreased comparing to fresh ice cream with increasing the storage period (Table 3 ), that might be caused by increasing the stickiness of the ice cream brought about by WPC incorporation in the ice cream mix.

\subsubsection{End of adhesiveness ( $\mathrm{mm}$ )}

The end of adhesiveness displacement reaches when the force is equal zero $\mathrm{N}$. This may not be $0.00 \mathrm{~N}$ if the sample sticks to the probe. In this situation the negative value should be increased to accommodate the weight of sample on the probe. The displacement shifted to the right on the back extrusion chart with increasing values significantly with increasing WPC\%, the storage period $(\mathrm{P}<0.001)$ and insignificantly $(\mathrm{P}>0.05)$ with the interaction of the two factors. WPC\% highly correlated with zero $\mathrm{N}(0.984)$.

Time at adhesive (sec.) helped in locating the end of adhesive contact e.g. break point between probe and sample. Time at adhesive decreased with increasing WPC\% and storage period. The stretching of the ice cream sample increased with increasing WPC\% $(\mathrm{P}<0.001)$ and decreased, comparing to fresh ice cream, with increasing the storage period, that might be caused by increasing the stickiness of the ice cream brought about by WPC incorporation in the ice cream mix.

\subsection{Sensory evaluation}

Panel evaluation is an important indicator of potential consumer preferences. Panelists scored the T4, the least flavor. T3 was the most acceptable flavor among the ice cream $(\mathrm{LSD}=0.4859$ at $0.05 \alpha$ level). Totally adding WPC enhanced the flavor significantly $(\mathrm{p}<0.001)$.

\section{CONCLUSION}

In this work an application of basic back extrusion approaches to an instrumental texture data set was described in the case of ice creams mixtures. As it can be argued from the results, the whole mechanical profiles proved to be able to describe the texture changes of the product and appeared as a helpful screening method to assess the texture of WPC ice creams. The result interpretation and analysis appeared as an operative tool for quantifying the textural attributes. The treatment of the whole mechanical profiles by means of basic back extrusion tools appeared as a promising approach. Obviously, the relevance of fundamental rheological approach could not be substituted: superior analytical performance in routine instrumental texture evaluation is possible through a combination of expertise in current food mechanical properties evaluation and consolidated data. The combination of rheological and sensory techniques can assure the sake of rapidity and simplicity required for the routine quality control operation in the food industry. The present work depicts a study on ice cream fortified with WPC and underlines a possible future direction for the strengthening of routine food objective texture analysis.

\section{REFERENCES}

[1] Karaman, S., Ömer, S.T., Ferhat, Y., Mustafa, Ç., Ahmed, K. and Mahmut, D. (2014). Physicochemical, bioactive, and sensory properties of persimmon-based ice cream: Technique for order preference by similarity to ideal solution to determine optimum concentration. J. Dairy Sci., 97, 97-110.

[2] Goff, H.D. and Hartel, R.W. (2013). Ice cream.. Pres springer, New York. pp. 453.

[3] López-Fandĩno, R. (2006). Functional improvement of milk whey proteins induced by high hydrostatic pressure. Crit. Rev. Food Sci. Nutr., 46, 351-363.

[4] Pihalanto-Lepp, (2001). A. Bioactive peptides derived from bovine whey proteins: opioid and ACE-inhibitory peptides. Trends Food Sci. Technol., 11, 347-356.

[5] Saito, T.; Nakamura, T.; Kitazawa, H.; Kawai, Y. and Itoh. T. (2000). Isolation and structural analysis of antihypertensive peptides that exist naturally in Gouda cheese. J. Dairy. Sci., 83, 1434-1440.

[6] Patel, M.R, Baer R.J, Acharya M.R. (2006). Increasing the protein content in ice cream. J. Dairy Sci., 89, 1400-1406. 
[7] Dahm, L. (2000). Diamond in the rough. The Cinderella story of whey protein ingredients. Dairy Field.133,20-27.

[8] Eisner, M.D.; Wildmoser, H. and Windhab, E.J. (2005). Air cell microstructuring in a high viscous ice cream matrix. Colloids and Surfaces A: Physicochemial and Engineering Aspects. 263, 39039.9

[9] Osorio, F. A. and Steffe, J. F. (1987). "Back Extrusion of Power Law Fluids," J. Texture Stud., 18, 43-63.

[10] Castilla O. S.; Calleros C. L.; Mandujano E. A.; Carter E.J. V. (2004). Microstructure and texture of yogurt as influenced by fat replacers. Int. Dairy J.14,151-159.

[11] Vargas M.; Chafer M.; Albors A.; Chiralt A.; Gonza' lez-Martı'nez C. (2008). Physicochemical and sensory characteristics of yoghurt produced from mixtures of cows' and goats' milk. Int. Dairy J.18,1146-1152.

[12] Brennan C. and Tudorica C. (2008). Carbohydratebased fat replacers in the modification of the rheological, textural and sensory quality of yoghurt: comparative study of the utilisation of barley betaglucan, guar gum and inulin. Int. J. of Food Science and Tech. 43, 824-833.

[13] Sendra E.; Kuri V.; Fernandez-López J.; SayasBarbera E.; Navarro C. and Perez-Alvarez J.A. (2010). Viscoelastic properties of orange fiber enriched yogurt as a function of fiber dose, size and thermal treatment. LWT-Food Science and Tech.43,708-714.

[14]Lejko D. N., ski D. Z., Ptaszek A. and Socha R. (2014). Textural properties of yogurts with green tea and Pu-erh tea additive. Int. J. of Food Science and Tech. 49, 1149-1158.

[15] Rawson H.L. and Marshall V.M. (1997). Effect of ropy strains of Lactobacillus delbrueckii ssp. And streptococcus thermophiles on rheology of stirred yoghurt. Int. J. of Food Sci. and Tech.32,213-220.

[16] Valerie M.; Marchall and Rawson, H. I. (1999). Effect of exopolysaccharide-producing strains of thermophilic lactic acid bacteria on the texture of stirred yoghurt. Int. J. of Food Sci., and Tech.34, 137-143.

[17] Pereira, R. B., Singh, H., Munro, P. A., and Luckman, M. S. (2003). Sensory and instrumental textural characteristics of acid milk gels. Int. Dairy J., 13, 655-667.

[18] Staffolo, M. D., Bertola, N., Martino, M., and Bevilacqua, y. A. (2004). Influence of dietary fiber addition on sensory and rheological properties of yogurt. Int. Dairy J.,14, 263-268.
[19] Patrignani, F., Iucci, L., Lanciotti, R., Vallicelli, M., Maina Mathara, J., Holzapfel, W. H., and Guerzoni M. E. (2007). Effect of high-pressure homogenization, nonfat milk solids, and milk fat on the technological performance of a functional strain for the production of probiotic fermented milks. J. of Dairy Sci.,90, 4513-4523.

[20]Ilicic M.D.; Milanovic S.D.; Caric M.D.; Vukic V.R. ; Kanuric K.G. ; Ranogajec M.I. and Hrnjez D.V. (2013). The effect of transglutaminase on rheology and texture of fermented milk products. J. of Texture Studies. 44, 160-168.

[21]Raju P. N. and Pal D. (2014). Effect of dietary fibers on physico-chemical, sensory and textural properties of Misti Dahi. J Food Sci Technol.,51,3124-3133.

[22] Piazza L.; Gigli J.; Rojas C.; Ballabio D.; Todeschini R. and Tripaldi P. (2009). Dairy cream response in instrumental texture evaluation processed by multivariate analysis. Chemometrics and Intelligent Laboratory Systems. 96,258-263.

[23] Nalesnik C.A.; Onwulata C.I.; Tunick M. H.;Phillips J. G. and Tomasula P.M. (2007). The effects of drying on the properties of extruded whey protein concentrates and isolates. J. of Food Eng. 80, 688694.

[24] Sinelli N.; Barzaghi S.; Giardiana C.; and Cattaneo T.M.P. (2005). A preliminary study using Fourier transform near infrared spectroscopy to monitor the self-life of packed industrial ricotta cheese. J. Near spectrosc. 13, 293-300.

[25] Cooper H.R. and Watts T.A. (1981). Evaluations of Textural Characteristics Produced In Cottage Cheese Creamed with Selected Dressings. Can. Inst. Food Sei. Techno. J. 14, I, 29-35.

[26] Marconi E.; Ruggeri S.; Cappelloni M.; Leonardi D.; and Carnovale E. (2000). Physicochemical, Nutritional, and Microstructural Characteristics of Chickpeas (Cicer arietinum L.) and Common Beans (Phaseolus vulgaris L.) Following Microwave Cooking. J. Agric. Food Chem.,48, 5986-5994.

[27] Sikora M.; Kowalski S.;Tomasik , P. and, Sady M. (2007). Rheological and sensory properties of dessert sauces thickened by starch-xanthan gum combinations. J. of Food Eng. 79,1144-1151.

[28]Heinzerling C.I; Smit G. and Dransfield E. (2008). Modelling oral conditions and thickness perception of a starch product. Int. Dairy J. 18, 867-873.

[29] Alvarez M. D.; Fernandez C.; Solas M. T.; and Canet W. (2011). Viscoelasticity and microstructure of inulin-enriched mashed potatoes: Influence of freezing and cryoprotectants. J. of Food Eng.,102, 66-76. 
[30] Afoakwa E. O.; Paterson A.; Fowler M. and Vieira J. (2009). Microstructure and mechanical properties related to particle size distribution and composition in dark chocolate. Int. J. of Food Science and Technology. 44, 111-119.

[31] Cevoli C.; Balestra F.; Ragni L.; and Fabbri A.. (2013). Rheological characterisation of selected food hydrocolloids by traditional and simplified techniques. Food Hydrocolloids. 33,142-150.

[32] Colombo A.; Edel Leo' n A. and Ribotta P. D. (2011). Rheological and calorimetric properties of corn, wheat, and cassava starches and soybean protein concentrate composites. Starch/Sta"rke. 63, 83-95 DOI 10.1002/star.201000095.

[33] AOAC. (2006). Official Methods of Analysis of the Association of Official Analytical Chemists $16^{\text {th }}$ edn., published by the Association of Official Analytical Chemists. Arlington, Virginia, 2220 USA.

[34] Lawrance A.J. (1968). The determination of lactose in milk products. Aust. J. Dairy Tech., 23, 103-106.

[35]Divide C.L. (1977). Laboratory Guide in Dairy Chemistry Practical. Press Dairy Training and Research Institute, Univ. of Philippines, Los Banos. ; pp.69.

[36] Awad R.A, Metwally (2000). A.I. Evaluation of total milk proteinate as a milk solids source in ice cream manufacture. Annals Agric. Sci., Ain Shams Uaniv., Cairo., 45,2, 603-618.

[37] Suneeta P, Prajapati J.P, Patel A.M, Patel H.G, Solanky M.J. (2007). Studies on the effect of whey protein concentrate in development of low-fat ice cream. Journal of Food Science and Technology. ,44,6 586-590. Cited from FSTA abstracts, 2008-03Pn0623.

[38] Parsons, J.G.; Dybing, S.T.; Coder, D.S.; Spurgeon, K.R. and Seas, S.W. (1985). Acceptability of ice cream made with processed whey and sodium caseinate. J. Dairy Sci.,68, 2880-2885. 